\title{
CARCASS TRAITS FOR GROWING BARKI LAMBS FED LIME TREATED AGRO-INDUSTRIAL BY-PRODUCTS
}

\author{
K. Zein Al-Abdein Kewan
}

Department of Animal Nutrition, Desert Research Center, Al-Mataria, P.O.Box 11753, Cairo, Egypt

\section{SUMMARY}

Date seeds (TDS) and olive pulp (TOP) treated with lime solution were incorporated as untraditional rations to study their effect on growth performance and carcass traits of Barki sheep. Thirty Barki male lambs (five months old and $27.98 \pm 1.97 \mathrm{~kg}$ average body weight) were assigned to three equal groups. The first group (control C) was fed on $30 \%$ clover hay $+70 \%$ concentrate feed mixture, concentrate feed mixture (CFM). The second group was fed $30 \%$ clover hay $+50 \%$ CFM + $10 \%$ TDS $+10 \%$ TOP (T1), the third group was fed $30 \%$ clover hay $+30 \%$ CFM+ $20 \%$ TDS $+20 \%$ TOP (T2). The actual voluntary feed intake, body weight changes and daily gain, the efficiency of feed conversion into live weight, carcass weight and economic evaluation were calculated.

Results revealed that, lambs fed control ration had the highest total dry matter intake (DMI) (1384 $\mathrm{g} / \mathrm{h} / \mathrm{d}$ ) compared with $\mathrm{T1}$ and $\mathrm{T} 2$ (1315 and $1199 \mathrm{~g} / \mathrm{h} /$ day, respectively). Average daily gain decreased with increasing treated date seed and olive pulp substituting the CFM. The best feed conversion was recorded for the control group followed by T1 and T2 groups. However, T1 was the least in feed cost of one $\mathrm{kg}$ gain, producing the highest economical efficiency. Control group revealed the highest $(P<0.05)$ values for dressing percentage (\%) based on either fasting body weight (FBW) or empty body weight $(E B W)$ (44.53 and 52.54, respectively), followed by $T 1$ group (42.70 and 49.24, respectively) and then T2 group ( 41.76 and 46.95 , respectively).

Keywords: By-products, lime, Barki sheep, growth, carcass

\section{INTRODUCTION}

Mutton represents the second source of the red meat in Egypt. Under different production systems, cost of producing one $\mathrm{kg}$ gain is extremely dependent on the feed quality consumed by animals. Many trials were conducted to describe the growth features of Barki sheep (Mokhtar et al., 1991 and Sami and Shehata, 2006) as well as carcass traits (El-Asheeri and Hafez, 2009).

The future prosperity of feed resources in Egypt relies on the economic feasible use of marginal and long-neglected resources such as date seeds and olive pulp. Effective use of these resources may decrease the amounts of concentrate feed offered to animals, hence reduce the feed cost, as well as limiting the environmental pollution (Abou Slim and Bendary, 2005).

Date seeds and olive pulp as agro-industrial by-products have been demonstrated by many investigators as acceptable feedstuffs for sheep and goats (Khattab, 2000; Youssef et al., 2001; Abd El-Rahman et al., 2003).

High crude fiber and lignin content represents one of the main problems of using these by-products in feeding farm animals which limit their usage in animal ration. Kewan et al. (2011) concluded that treatment with lime solution at level $12 \%$ for four weeks improved chemical component and reduced acid detergent lignin content for both date seeds and olive pulp. Moreover, it increased both in situ DM and OM digestibility.

The objective of the present study was to investigate the effect of incorporating date seeds and olive pulp treated with lime solution in Barki sheep rations on carcass traits.

\section{MATERIALS AND METHODS}

The present study was carried out at Maryout Experimental Research Station, Desert Research Center. Un-slaked lime was dissolved in water at level of $12 \%(\mathrm{w} / \mathrm{w})$, so, the actual lime solution level is $3.96 \%$. The supernatant of lime solutions were sprayed manually $(350 \mathrm{ml} /$ one $\mathrm{kg} \mathrm{DM})$ on the raw materials of date seeds and olive pulp and then mixed thoroughly by hand (final moisture concentration ranged from 35 to $40 \%$ ) before keeping in polyethylene bags. Bags of the treated materials were sealed completely and kept for four weeks. At the end of incubation period, samples were taken and dried at $70^{\circ} \mathrm{C}$ for $24 \mathrm{hr}$ before chemical composition determination.

Thirty Barki male lambs (five months old) with an average body weight of $27.98 \pm 1.97 \mathrm{~kg}$ were assigned randomly into three equal groups (10 lambs each). The experiment started September, 2007 and lasted for 100 days. Each group was housed separately in 
shaded pen ( 5 X 6 meter). The three groups were randomly assigned to receive one of the three experimental rations.

The three experimental rations were formulated using date seeds and olive pulp treated with $12 \%$ lime for four weeks as follows: (C): $30 \%$ clover hay $+70 \% \mathrm{CFM}$; (T1): $30 \%$ Clover hay $+50 \%$ CFM $+10 \%$ treated date seeds (TDS) $+10 \%$ treated olive pulp (TOP) and (T2): $30 \%$ Clover hay $+30 \%$ $\mathrm{CFM}+20 \% \mathrm{TDS}+20 \%$ TOP. The concentrate feed mixture (CFM) consisted of $35 \%$ undecorticated cotton seed cake, $33 \%$ wheat bran, $22 \%$ yellow corn grains, $4 \%$ rice bran, $3 \%$ molasses, $1 \%$ salt and $2 \%$ limestone). The quantities of rations offered to each group were about $4 \%$ of their average body weight. The actual voluntary feed intake was recorded daily for each group. Fresh water was available to the animals at free choice all day. Body weight changes and daily gain were recorded biweekly for each animal. Feed conversion efficiency either into live weight or carcass weights as well as economic evaluation were calculated.

At the end of growth trials, three animals from each treatment were weighed and slaughtered in accordance with Islamic method. After skinning, all abdominal and thoracic organs were removed and carcasses were weighed. The alimentary tracts were weighed full and empty; the weights of their contents were calculated by subtraction. Weight of gut contents was subtracted from slaughter weight to obtain the empty body weight (EBW). Hot carcass weight was expressed as percentage of slaughter weight and empty body weight to estimate dressing percentage (Koch et aI., 1963). Accordingly, the fat tail and kidney fat were left on the carcass.

The carcasses were refrigerated for 24 hours at an average temperature of $4{ }^{\circ} \mathrm{C}$ (Frild et al., 1963). Chilled carcass were then weighed and wholesale cuts, legs, loin, rack, shoulder, flank, neck and tail were each weighed separately. Weights of the wholesale cuts were calculated as percentage of cold carcass weight.

The area of the Longissimus dorsi (LD), muscle was measured as the area of its cross section between the $11^{\text {th }}$ and $12^{\text {th }}$ ribs in $\mathrm{cm}^{2}$. Drawing the outline of the L.D muscle of both sides using a plastic sheet was done. The mean area of both drawings was then obtained by using a digital Planimeter according to Henderson et al. (1966). Ribs 9, 10 and 11 were separated into its physical contents: fat, lean and bones.

Chemical composition (DM, OM, CP, CF, $\mathrm{EE}$ and NFE) of feeds was determined according to the procedure of A.O.A.C (1990).
Nitrogen free extract was calculated by difference .Neutral detergent fiber (NDF), acid detergent fiber (ADF) and acid detergent lignin (ADL) were analyzed using the procedure of Van Soest et al. (1991).

The Longissimus dorsi muscle and meat (the resulted lean and fat from the 9, 10 and 11 ribs) were used for chemical analysis. The samples were minced several times to be homogeneous and a sample of the mixture of each animal was kept frozen for chemical analysis. Moisture, ash, protein and fat contents were determined according to the procedure of A.O.A.C (1990).

Economic indicators were calculated in Egyptian pounds (L.E.) based on the price of the year 2009. The prices were assigned as follows; Berseem hay L.E. 1000/ton; concentrate feed mixture L.E. 1500/ton; ground date seeds L.E. 700/ ton; and olive pulp L.E. 525/ ton. The price of one $\mathrm{kg}$ live body weight at purchase or selling was L.E. 24. Economic indicators were calculated as:

- $\quad$ Total variable cost (L.E.) $=$ Feeding cost + Purchase price

- Revenue (L.E.) = Total income - Total variable cost

- Cost of feeding to produce one $\mathrm{kg}$ gain (L.E.) = Feeding cost / Total gain

- Return / cycle percent = Revenue / Total variable cost

Data was statistically analyzed using GLM for repeated measurements according to SAS (1998). The model used for growth trial was: $\mathrm{Y}_{\mathrm{ij}}=\mu+\mathrm{T}_{\mathrm{i}}+\mathrm{e}_{\mathrm{ij}}$. Where: $\mathrm{Y}_{\mathrm{ij}}=$ experimental observation; $\mu=$ general mean; $\mathrm{T}_{\mathrm{i}}=$ effect of tested ration; $\mathrm{e}_{\mathrm{ij}}=$ experimental error.

Differences among groups were compared by Duncan's Multiple Range Test (Duncan, 1955).

\section{RESULTS AND DISCUSSION}

\section{Chemical composition of the experimental rations:}

The chemical composition of rations formulated with TDS and TOP (20 or 40\%) was nearly similar to the control ration (C) (Table 1). Results showed linear decrease in the contents of OM, CP, EE and NFE with increasing the replacement rate of experimental mixture. Meanwhile, incorporating the experimental mixture in rations increased the content of ash, $\mathrm{CF}, \mathrm{ADF}$ and ADL of $\mathrm{T} 1$ and $\mathrm{T} 2$ compared with $\mathrm{C}$ ration. These results are in agreement with the finding of Khattab (2000) and Hassan and Irhaif (2009) but contrasted with the findings of Chaudhry (2000). 


\section{Feed intake and growth traits:}

Feed intake (expressed as DM) for Barki lambs fed the experimental rations is presented in Table (2). Lambs fed $\mathrm{C}$ ration had the highest total DMI (1384 g/h/d) compared with T1 and T2 (1315 and $1199 \mathrm{~g} / \mathrm{h} /$ day, respectively). This decrease in DMI might be due to increasing fiber content in $\mathrm{T} 1$ and $\mathrm{T} 2$ (Table 1), which agrees with the results obtained by Nassar, (2002); Abou El-Nasr and El-Kerdawy, (2003), but contrasted with that reported by Nefzaoui et al. (1983), who found a considerable improvement of nutritive value for olive cake when injected with $3 \% \mathrm{NH}_{3}$. Such differences may reflect the effect of different alkali treatments.

Data in Table (2) showed no significant differences between lambs of $\mathrm{C}$ group and those fed $\mathrm{T} 1 \mathrm{regarding}$ final weight $(\mathrm{FW}, \mathrm{kg})$, total gain $(\mathrm{kg})$ and average daily gain (ADG, $\mathrm{g} / \mathrm{d})$. Lambs of $\mathrm{T} 2$ showed lower $(\mathrm{P}<0.05) \mathrm{FW}$, total gain and $\mathrm{ADG}$ by 10.77, 26.14 and $26.14 \%$, respectively relative to $\mathrm{C}$ group. These results agree with those found by Sooud et al. (1989) reporting a linear decrease in the ADG with increasing the percentages of treated date seed and olive pulp in the ration. This decrease might be attributed to the reduction in DMI with increasing the substitution level (Table 2), which supported by the findings of Mioč et al. (2007).

Better feed conversion was recorded for the $\mathrm{C}$ followed by $\mathrm{T} 1$ and $\mathrm{T} 2$ groups (Table 2). The present result lies within the range reported by Youssef and Fayed (2001), Abou El-Nasr and El-Kerdawy (2003) and Al-Ani and Farhan (2009). Increasing the inclusion level of olive pulp ( $10 \%$ to $20 \%$ ) in $\mathrm{T} 2$ ration resulted in a reduction in $\mathrm{FW}, \mathrm{ADG}$ and feed conversion, which agrees with the results of Mostafa (2003).

\section{Economic indicators:}

$\mathrm{T} 1$ group showed higher revenue and lower cost of feeding to produce one $\mathrm{kg}$ gain as compared to the other groups (Table 2).

\section{Carcass traits:}

Lambs slaughter data in terms of fasting weight (FBW), empty body weight (EBW), carcass weight $(\mathrm{CW})$, dressing percentage (D $\%$ ) and whole sale cuts for lambs fed the experimental rations are shown in Table (3). Lambs of $\mathrm{C}$ and $\mathrm{T} 1$ groups showed comparable values for FBW and EBW. It can be seen that, EBW was affected by FBW, which related to feed intake as shown in Table (2).

$C$ group revealed the highest $(\mathrm{P}<0.05)$ values for $\mathrm{CW}$ and $\mathrm{D} \%$ based on either FBW or EBW followed by $\mathrm{T} 1$ and then $\mathrm{T} 2$ groups. These findings might be due to the higher nutritive value for control diet than the other two diets (Table 1). These results are in agreement with those obtained by Gorgulu et al. (1994) and Taie et al. (1998) who found that dressing percentage was higher with high energy diet than with low energy diet.

Dressing percentage based on either FBW or EBW for the experimental lamds ranged from 41.76 to $44.53 \%$ and from 46.95 to $52.54 \%$, respectively. Results of dressing percentage based on FBW are close to that reported by Sami and Shehata (2006) (44.4\%) and lower than that reported by Galal et al. (1975) (57\%) and by El-Asheeri and Hafez (2009) (52.2\%). The present data were contrasted with that reported by Eid (1998) and Abdou (1998), who found that the rations contain agro-industrial by-products and organic waste had no apparent effect on dressing percent. Also, Khattab (2000) and Mioč et al. (2007) suggested that the addition of $15 \%$ of olive cake to the concentrate had no significant negative effect on carcass weight and dressing percentage of lambs. Moreover, Abd El-Rahman et al. (2003) reported no significant differences in dressing percentage between sheep fed diet contained $22 \%$ date seeds and $15 \%$ olive pulp compared with sheep fed control diet.

Mean percentages of the wholesale cuts (legs, flank, loin rack, shoulder and neck) based on CW are presented in Table (3). All the wholesale cuts values were significant among the experimental groups. Animals received ration $\mathrm{T} 1$ showed values $(\mathrm{P}<0.05)$ between the other two groups. These results confirm that lambs utilized control diet better than the other two diets.

Organs percentage (head, leg, pelt and tail) for lamb carcass based on FBW is presented in Table (3). There were no marked differences among studied groups in head and leg \%. However, pelt and tail percentages based on FBW were significantly $(\mathrm{P}<0.05)$ different among treatment groups. Control group recorded the highest values of pelt and tail being 13.78 and $2.03 \%$, respectively. No differences were noticed between $\mathrm{C}$ and $\mathrm{T} 1$ groups in pelt percent and between $\mathrm{C}$ and $\mathrm{T} 2$ groups in tail percent. Moreover, the lowest values were recorded for $\mathrm{T} 1$ in pelt percent and $\mathrm{T} 2$ in tail percent.

Offal's percentage (heart, liver and kidney) for lamb carcass based on FBW are presented in Table (3). Heart percent was higher $(\mathrm{P}<0.05)$ in $\mathrm{C}$ group with no significant difference with T1. However, T2 group has the lowest value of heart percent. Liver and kidney percentages have the same trend, the obtained results revealed that, $\mathrm{C}$ group has the highest values followed by $\mathrm{T} 1$ and $\mathrm{T} 2$. These results 
reflect that, the internal organs related to diet metabolism were affected $(\mathrm{P}<0.05)$ by the nutritive value of those diets.

Significant $(\mathrm{P}<0.05)$ differences in carcass fat components percentage based on fasting body weight (except for kidney fat) due to feeding the experimental rations are shown in Table (3). Lambs fed T1 and T2 deposit lower internal fat, total body fat and fat \% than $\mathrm{C}$ group. The present results are in agreement with the findings of Abd El-Rhman et al. (2003) for sheep fed diets contained $22 \%$ date seeds and $15 \%$ olive.

\section{Physical components and chemical composition of eye muscle:}

Physical component (area $\mathrm{cm}^{2}$, lean\%, fat $\%$, bone $\%)$ differed $(\mathrm{P}<0.05)$ among the studied groups (Table 4). The present results don't conform to the findings of Khattab (2000) who recorded no effect of diet on physical parameters. Eye muscle area was affected significantly by the experimental diets; where it was lower in $\mathrm{T} 2$ than in $\mathrm{C}$ group and lower in $\mathrm{T} 1$ than in $\mathrm{C}$ group.

This is in contrast with the result reported by Abd El-Rahman et al. (2003) with sheep fed diets contained $22 \%$ date seeds and $15 \%$ olive pulp. $\mathrm{C}$ group had higher values of eye muscle area followed by $\mathrm{T} 1$ and $\mathrm{T} 2$ in descending order. The higher eye muscle area is a good indicator for high growth, protein deposition and carcass quality (Karr et al, 1965). The significant effect of diets on lean percentage might be due to the significant of nitrogen retention (Kewan et al., 2011). Lambs of $\mathrm{T} 2$ showed higher $(\mathrm{P}<0.05)$ bone percentage than the other two groups. This might be due to the higher intake of byproducts treated by $\mathrm{Ca}(\mathrm{OH})_{2}$. Lamb of $\mathrm{T} 1$ had middle values among the other two group values for eye muscle component (lean, fat, bone and lean to bone ratio). However, T1 group had the highest value in lean/fat ratio being $4.20 \%$ followed by the other two groups.

\section{Chemical composition:}

Values of chemical composition of eye muscle for lambs fed different percent of alkali treated by-products are illustrated in Table (4). No significant differences were noticed among groups fed the experimental diets with regard to moisture, DM, CP, EE and ash contents. Khattab (2000) observed similar results with Barki male lambs fed date seeds that covered 50 and $75 \%$ of maintenance energy requirement.

\section{CONCLUSION}

Based on the nutritional and economical results of the present work, it could be concluded that, $20 \%$ of concentrate feed mixture could be replaced by the same amount of a mixture of lime treated date seed and olive pulp (1:1) in lamb rations, with no adverse effect on meat quality.

\section{REFERENCES}

Abd El-Rahman, G.A., H.M. Abou El-Nasr, M.S. Ayyat, A.M. Fayed and M.S. Nassar, 2003. Utilization of some agro-industrial by-products in fattening lambs on the natural ranges in the South of valley. Egyptian. J. Nutr. and Feeds., 26: 851-865.

Abdou, A.R., 1998. Utilization of organic wastes as animal feed in Sinai. M. Sc. Thesis, Fac. Agric., Cairo Univ., Egypt.

Abou El-Nasr, H.M. and D.M.A. El-Kerdawy, 2003. Effects of complete replacement of the common feed mixture by agroindustrial by-products on performance of growing lambs under desert conditions of Egypt. Egyptian J. Nutr. And Feeds., 26: 803-810.

Abou Slim, I.A. and M.M. Bendary, 2005. Feed stuff resources in Egypt: Sources and maximization of its utilization. Animal Production Research Institute, Second Conference \& Regional Symposium on Buffalo Production,27-29 September, 2005, Sakha, Kafr El-Sheikh, Egypt.

Al-Ani, A.N. and S.M.A Farhan, 2009. The effect of various sources of nitrogen with date stones in fattening diets of Awassi lambs. Egyptian J. Anim. Feeds., and Nutrition., (Special Issue). Proceeding of the 12th Scientific Conference of Animal Nutrition. 20-23 October, 2009., 12(3): 285-289

AOAC, 1990. Association of Official Analytical Chemists. Official Methods of Analysis, 15th Ed. Washington, D C., USA.

Chaudhry, A.S., 2000. Rumen degradation in sacco in sheep of wheat straw treated with calcium oxide, sodium hydroxide and sodium hydroxide plus hydrogen peroxide. Anim.Feed Sci. Technol., 83: 313-323.

Duncan D.B., 1955. Multiple range and multiple F-test.Biometrics., 11: 1-42.

Eid, E.Y.A., 1998. Effect of organic wastes utilization in ruminants feeding on animal performance under desert conditions. M.Sc. Thesis, Fac. Agric., Zagazig Univ., Egypt

El-Asheeri, Amal, K., and Y.M. Hafez, 2009. Prelimenary indicators of growth, carcass and economic traits of yearling Ossimi and Barki lambs. Egyptian J. Anim. Prod., 46 (1): 35-42.

Frild, R.A., J.D. Kempt and W.Y. Varney, 1963. Indices for lambs carcass composition. J. Anim. Sci., 22:2118. 
Galal, E.S.E., Y.S. Ghanem, M.A. Farid, M.H. Fahmy and A. E.M. Soudy, 1975. Carcass traits and feed lot performance of Barki, Merino and Awassi breeds of sheep and some of their crosses. Egyptian J. Anim. Prod., 15:33-41.

Gorgulu, M., O.O. Zturkcan, E.S.E. Galal, O. Gursory, 1994. Effect of dietary energy and protein levels on fattening performance of Awassi lambs. Strategies for the development of fat tail sheep in the NearEast-proceedings. Adana-Turky, 66-69.

Hassan, A.A. and S.H. Irhaif, 2009. Physical and some chemical treatments and date palm syrup (DIPS) supplement effect on chemical composition and in vitro digestibility for barley straw. Egyptian J. Anim. Feeds., 12(3): 535-552.

Henderson, W.D., D.E. Goll, M.H. Stromer and M.I. Walter, 1966. Effect of different measurement techniques and operators on bovine logissimus dorsi area. J. Anim. Sci., 25:334-339.

Hungate, R.E. 1966. The Rumen and Its Microbes. Academic Press, USA.

Karr, M . R., U.S. Garrigus, E.E. Hatfield and H.W. Norton, 1965. Factors affecting the utilization of nitrogen from different sources by lambs. J. Anim. Sci., 24: 459468

Kewan, K.Z, M.A. Ali, M.A. Hanafy and E.S. Ashmawy, 2011. Performance of growing sheep fed rations containing lime treated date seeds and olive pulp. Egyptian, J. Nutr. Feeds 14 (2): 205:216.

Khattab, I.A., 2000. Nitrogen metabolism in ruminant nutrition. Effect of feeding some rangeland desert plants on productivity for growing sheep and goats in North Western Coastal zone. M.Sc. Thesis, Fac. Agric., Alex. Univ., Egypt.

Koch, R.M., L.A. Siger, D. Chambers, K.E. Gregory, 1963. Efficiency of feed use in beef cattle. J. Anim. Sci., 22:486- 494 .

Mioč, B., V. Pavić, I. Vnučec, Z. Prpić, A. Kostelić, V. Sušić, 2007. Effect of olive cake on daily gain, carcass characteristics and chemical composition of lamb meat. Czech J. Anim. Sci., 52 (2): 31-36.

Mokhtar, M.M, H. Mansour, A. Younis and H. El- Gabbas, 1991. Growth and mature size in fat-tailed Barki sheep. Egyptian J. Animal Production, 28 (2): 41-48.

Mostafa, M.R.M. 2003. Utilization of olive cake in fattening rations of Rahmani lambs. Egyptian J. Nutr. and Feeds., 6 (Special Issue): 811-820.
Nassar, M.S. 2002. Utilization of some agroindustrial byproducts in fattening lambs on the natural ranges in the South Vally. M. Sc. Thesis, Fac Agric. Zagazig Univ., Egypt.

Nefzaoui, A., PH. Hellings and M. Vanbelle, 1983. Ensiling olive pulp with ammonia; Effects on voluntary intake and digestibility measured by sheep. 34th Annual Meeting of the EAAP, Madrid, 3-6 October 1983.

Salem, O.M., M.A. Hanafy, I. Abd EI-Moty, A. El-Mole and G. M. Rakha, 1989. Effect of using agro-industrial by-products on sheep performance. 3rd Egyptian-British Conference on Animal, Fish and poultry Production, Alex. 7-10 October, 1989, 81$89 \mathrm{P}$.

Sami, A.S. and M.F. Shehata, 2006. Effect of dietary vitamin E supplementation on meat production related traits of Barki lambs. Egyptian J. Anim. Prod., 43(1):49-56.

SAS, 1998. Users Guide statistics version 6, 4th ed., vol. 2 SAS Institute, Inc., Cary. NC. USA.

Sooud, A.0., H.M. Abou EI-Nasr, E.A. Gihad, E.A. and T.T. Gallad, 1989. Fattening male lambs on the by-products mixture silage as a feed for lactating cattles and buffaloes. Alex. J. Agric. Res., 30(1):71-83.

Taie, H.T., M.M. Abdel-Rahman, B.M. Ahmed and Shereen H. Awara, 1998. Effect of dietary energy on digestibility, rumen fermentation, digestion kinetics, performance and carcass traits for sheep. The first international conference on animal production and health in semi arid areas. El-Arish, Egypt, 1-3 September, 1998, pp 351- 365.

Van Soest, P..J., J.B. Robertson and B.A. Lewis, 1991. Methods for dietary fiber, neutral detergent fibre and nonstarch polysaccharides in relation to animal nutrition. J. Dairy Sci., 74: 3583-3597.

Youssef, K.M. and A.M. Fayed, 2001. Utilization of some organic wastes as feed supplement for growing goats under desert conditions. Egyptian J. Nutrition and Feeds., 4:91-99.

Youssef, K.M., A.M. Fayed and H.S. Khamis, 2001. Productive and reproductive performance of ewes and does fed nonconventional diets based on olive pulp in Sinai. Egyptian J. Nutr. and Feeds., 591604. 
Table 1. Chemical composition (DM basis) of feed ingredients and experimental rations

\begin{tabular}{|c|c|c|c|c|c|c|c|}
\hline \multirow[b]{2}{*}{ Item } & \multicolumn{4}{|c|}{ Feed ingredients } & \multicolumn{3}{|c|}{ Experimental rations $^{4}$} \\
\hline & Hay & CFM $^{1}$ & $\begin{array}{c}\text { Treated } \\
\text { date seeds } \\
\text { (TDS) }\end{array}$ & $\begin{array}{c}\text { Treated } \\
\text { olive pulp }^{3} \\
\text { (TOP) }\end{array}$ & $\mathbf{C}$ & T1 & $\mathbf{T 2}$ \\
\hline \multicolumn{8}{|c|}{ Chemical composition, g/kg DM: } \\
\hline DM & 865.7 & 914.7 & 925.5 & 927.5 & 899.4 & 901.0 & 902.6 \\
\hline Ash & 95.9 & 21.6 & 63.5 & 80.1 & 43.9 & 50.9 & 57.9 \\
\hline $\mathrm{OM}$ & 904.1 & 978.4 & 936.5 & 919.9 & 956.1 & 949.1 & 942.1 \\
\hline $\mathrm{CP}$ & 132.1 & 140.8 & 68.5 & 85.0 & 138.2 & 129.2 & 120.3 \\
\hline $\mathrm{CF}$ & 244.2 & 129.1 & 123.1 & 283.1 & 163.6 & 174.0 & 184.4 \\
\hline $\mathrm{EE}$ & 23.1 & 55.4 & 20.7 & 10.2 & 45.7 & 40.1 & 34.5 \\
\hline NFE & 504.7 & 653.1 & 724.2 & 541.6 & 608.6 & 605.8 & 602.9 \\
\hline \multicolumn{8}{|c|}{ Fiber fraction, $\mathrm{g} / \mathrm{kg}$ DM: } \\
\hline $\mathrm{NDF}$ & 746.7 & 529.1 & 536.5 & 613.8 & 594.4 & 600.8 & 607.3 \\
\hline $\mathrm{ADF}$ & 471.8 & 214.0 & 469.6 & 477.6 & 291.3 & 324.2 & 357.0 \\
\hline $\mathrm{ADL}$ & 78.0 & 97.6 & 114.3 & 202.3 & 91.7 & 100.2 & 108.7 \\
\hline $\mathrm{HC}$. & 274.9 & 315.1 & 66.9 & 136.2 & 303.1 & 276.6 & 250.3 \\
\hline C. & 393.8 & 116.4 & 355.3 & 275.3 & 199.6 & 224.0 & 248.3 \\
\hline \multicolumn{8}{|c|}{ Nutritive value7, \% } \\
\hline TDN & - & - & - & - & 74.97 & $70.84 b$ & 68.08 \\
\hline DCP & - & - & - & - & 10.17 & 8.88 & 8.43 \\
\hline
\end{tabular}

Table 2. Feed intake, live body weight changes and feed conversion for growing Barki lambs fed on the experimental rations (n= 10/group)

\begin{tabular}{|c|c|c|c|c|}
\hline \multirow{2}{*}{ Items } & \multicolumn{3}{|c|}{ Experimental rations* } & \multirow{2}{*}{$\pm \mathrm{SE}$} \\
\hline & $\mathrm{C}$ & T1 & $\mathbf{T 2}$ & \\
\hline \multicolumn{5}{|l|}{ Feed intake (as DM), g/h/d: } \\
\hline Clover hay & 415 & 422 & 382 & ----- \\
\hline Concentrate feed mixture & 969 & 714 & 590 & ----- \\
\hline Treated by-products** & ------ & 179 & 227 & ----- \\
\hline Total & 1384 & 1315 & 1199 & ----- \\
\hline \multicolumn{5}{|l|}{ Body weight: } \\
\hline Initial weight, $\mathrm{kg}$ & 27.60 & 29.00 & 27.33 & 1.45 \\
\hline Final weight, $\mathrm{kg}$ & $45.20^{\mathrm{a}}$ & $45.40^{\mathrm{a}}$ & $40.33^{\mathrm{b}}$ & 1.78 \\
\hline Total gain, $\mathrm{kg}$ & $17.60^{\mathrm{a}}$ & $16.40^{\mathrm{a}}$ & $13.00^{\mathrm{b}}$ & 0.70 \\
\hline Average daily gain, $\mathrm{g} / \mathrm{d}$ & $176^{\mathrm{a}}$ & $164^{\mathrm{a}}$ & $130^{\mathrm{b}}$ & 7.01 \\
\hline \multicolumn{5}{|l|}{ Feed conversion: } \\
\hline kg DM /kg gain & 7.86 & 8.02 & 9.22 & ---- \\
\hline \multicolumn{5}{|l|}{ Economic indicators } \\
\hline Feeding cost, LE & 206.9 & 177.4 & 156.5 & ----- \\
\hline Purchasing price, LE & 662.4 & 696.0 & 655.9 & ----- \\
\hline Total variable cost & 869.3 & 873.4 & 812.1 & ----- \\
\hline Selling price, LE & 1084.8 & 1089.6 & 967.9 & ----- \\
\hline Revenue, LE & 215.5 & 216.2 & 155.0 & ---- \\
\hline Cost of feeding to produce $1 \mathrm{~kg}$ gain, $\mathrm{LE}$ & 11.67 & 10.82 & 12.04 & ----- \\
\hline Return/cycle, \% & 24.79 & 24.75 & 19.09 & ----- \\
\hline
\end{tabular}


Table 3. Dressing percentage and whole sale cuts for lambs fed the experimental rations

\begin{tabular}{|c|c|c|c|c|}
\hline \multirow[b]{3}{*}{ Items } & \multicolumn{4}{|c|}{$(n=3 /$ group $)$} \\
\hline & \multicolumn{3}{|c|}{ Experimental rations* } & \multirow{2}{*}{$\pm \mathbf{S E}$} \\
\hline & $\mathbf{C}$ & T1 & $\mathbf{T 2}$ & \\
\hline Fasting body weight (FBW), kg & $45.10^{\mathrm{a}}$ & $44.85^{\mathrm{a}}$ & $40.03^{b}$ & 0.84 \\
\hline Empty body weight $(\mathrm{EBW})^{* *}, \mathrm{~kg}$ & $38.27^{\mathrm{a}}$ & $38.87^{\mathrm{a}}$ & $35.60^{\mathrm{b}}$ & 0.52 \\
\hline Carcass wt $(\mathrm{CW}), \mathrm{kg}$ & $20.07^{\mathrm{a}}$ & $19.13^{\mathrm{b}}$ & $16.73^{\mathrm{c}}$ & 0.50 \\
\hline Dressing $\%$ based on $\mathrm{FBW}^{1}$ & $44.53^{\mathrm{a}}$ & $42.70^{\mathrm{b}}$ & $41.76^{\mathrm{c}}$ & 0.78 \\
\hline Dressing $\%$ based on $\mathrm{EBW}^{2}$ & $52.54^{\mathrm{a}}$ & $49.24^{\mathrm{b}}$ & $46.95^{\mathrm{c}}$ & 0.81 \\
\hline \multicolumn{5}{|l|}{ Whole sale cuts, $\%$ of CW } \\
\hline Legs & $34.61^{\mathrm{a}}$ & $32.44^{\mathrm{b}}$ & $29.72^{c}$ & 0.73 \\
\hline Flank & $4.98^{\mathrm{b}}$ & $5.57^{\mathrm{b}}$ & $8.27^{\mathrm{a}}$ & 0.53 \\
\hline Loin & $8.65^{\mathrm{a}}$ & $7.45^{\mathrm{b}}$ & $6.82^{\mathrm{c}}$ & 0.28 \\
\hline Rack & $20.00^{\mathrm{c}}$ & $23.68^{\mathrm{b}}$ & $28.31^{\mathrm{a}}$ & 1.21 \\
\hline Shoulder & $19.40^{\mathrm{a}}$ & $18.44^{\mathrm{b}}$ & $16.65^{\mathrm{c}}$ & 0.41 \\
\hline Neck & $12.23^{\mathrm{a}}$ & $12.09^{\mathrm{a}}$ & $9.83^{\mathrm{b}}$ & 0.39 \\
\hline \multicolumn{5}{|l|}{ Organs, $\%$ of FBW } \\
\hline Head & 5.94 & 6.28 & 6.09 & 0.16 \\
\hline Feet & 1.98 & 2.26 & 2.06 & 0.06 \\
\hline Pelt & $13.78^{\mathrm{a}}$ & $13.01^{\mathrm{a}}$ & $11.47^{\mathrm{b}}$ & 0.39 \\
\hline Tail & $2.03^{\mathrm{a}}$ & $1.63^{\mathrm{b}}$ & $1.96^{\mathrm{a}}$ & 0.06 \\
\hline \multicolumn{5}{|l|}{ Offals, $\%$ of FBW } \\
\hline Heart & $0.43^{\mathrm{a}}$ & $0.42^{\mathrm{a}}$ & $0.35^{\mathrm{b}}$ & 0.02 \\
\hline Liver & $1.50^{\mathrm{a}}$ & $1.31^{\mathrm{b}}$ & $1.26^{\mathrm{b}}$ & 0.04 \\
\hline Kidney & $0.39^{\mathrm{a}}$ & $0.29^{\mathrm{b}}$ & $0.22^{\mathrm{b}}$ & 0.08 \\
\hline \multicolumn{5}{|l|}{ Fat components as $\%$ of FBW } \\
\hline Tail fat & $1.97^{\mathrm{a}}$ & $1.63^{\mathrm{b}}$ & $1.99^{\mathrm{a}}$ & 0.06 \\
\hline Kidney fat & 0.30 & 0.31 & 0.35 & 0.01 \\
\hline Internal fat & $0.57^{\mathrm{a}}$ & $0.49^{\mathrm{ab}}$ & $0.43^{\mathrm{b}}$ & 0.02 \\
\hline Total body fat, kg & $1.28^{\mathrm{a}}$ & $1.09^{\mathrm{b}}$ & $1.11^{\mathrm{b}}$ & 0.03 \\
\hline $\mathrm{Fat}^{3}$ & $2.83^{\mathrm{a}}$ & $2.43^{\mathrm{b}}$ & $2.78^{\mathrm{a}}$ & 0.08 \\
\hline \multicolumn{5}{|c|}{$\begin{array}{l}* \mathrm{C}: \text { control ration: clover hay } 30 \%+\mathrm{CFM} 70 \% ; \mathrm{T} 1: \text { clover hay } 30 \%+\mathrm{CFM} 50 \%+\mathrm{TDS} 10 \%+\mathrm{TOP} 10 \% ; \mathrm{T} 2 \\
\text { clover hay } 30 \%+\mathrm{CFM} 30 \%+\mathrm{TDS} 20 \%+\mathrm{TOP} 20 \% \text {. } \\
* * \text { Empty body weight, } \mathrm{kg}=\text { fasting weight }- \text { rumen content weight } \\
{ }^{1} \text { dressing } \%=\text { carcass wt } / \text { fasting wt } * 100 \\
{ }^{2} \text { dressing } \%=\text { carcass wt } / \text { fasting wt }- \text { rumen content wt } * 100 \\
{ }^{3} \text { Fat } \%=\text { Total fat/fasting weight } * 100 .\end{array}$} \\
\hline
\end{tabular}

Table 4. Physical components and chemical analysis of eye muscle of Barki lambs fed on lime solution treated by-products

\begin{tabular}{|c|c|c|c|c|}
\hline \multirow{2}{*}{ Items } & \multicolumn{3}{|c|}{ Experimental rations* } & \multirow{2}{*}{$\pm \mathrm{SE}$} \\
\hline & $\mathrm{C}$ & $\mathrm{T} 1$ & $\mathrm{~T} 2$ & \\
\hline \multicolumn{5}{|c|}{ Physical component of L.D. } \\
\hline L.D. area, $\mathrm{cm} 2$ & $22.33^{\mathrm{a}}$ & $20.60^{\mathrm{ab}}$ & $18.47^{\mathrm{b}}$ & 0.62 \\
\hline Lean $\%$ & $69.57^{\mathrm{a}}$ & $67.74^{\mathrm{b}}$ & $64.83^{\mathrm{c}}$ & 0.74 \\
\hline Fat $\%$ & $18.38^{\mathrm{a}}$ & $16.13^{\mathrm{b}}$ & $17.25^{\mathrm{ab}}$ & 0.37 \\
\hline Bone $\%$ & $12.06^{\mathrm{c}}$ & $16.13^{\mathrm{b}}$ & $17.92^{\mathrm{a}}$ & 0.88 \\
\hline Lean : Fat ratio & $3.80^{\mathrm{b}}$ & $4.20^{\mathrm{a}}$ & $3.76^{\mathrm{b}}$ & 0.09 \\
\hline Lean : Bone ratio & $5.77^{\mathrm{a}}$ & $4.20^{\mathrm{b}}$ & $3.62^{\mathrm{c}}$ & 0.96 \\
\hline \multicolumn{5}{|c|}{ Chemical analysis (\%) of L.D. muscle on DM basis } \\
\hline Moisture & 73.50 & 73.68 & 73.57 & 0.16 \\
\hline $\mathrm{DM}$ & 26.50 & 26.32 & 26.43 & 0.16 \\
\hline $\mathrm{CP}$ & 64.55 & 63.36 & 63.87 & 0.49 \\
\hline $\mathrm{EE}$ & 28.72 & 28.62 & 27.81 & 0.29 \\
\hline Ash & 4.20 & 4.40 & 4.32 & 0.16 \\
\hline
\end{tabular}




\section{صفات الذبيحة لذكور الاغنام البرقي النامية المغذاة على مخلفات التصنيع الزراعي المعاملة بالجير خالا زين العابدين كيوان}

\section{قسم تغذية الحيوان والدواجن، مركز بحوث الصحراء، المطرية، ص.ب 11753، القاهرة، جم.ع}

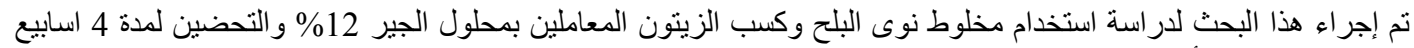

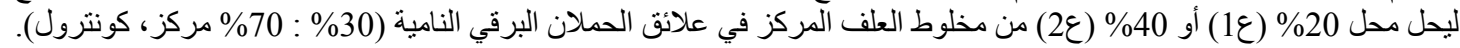

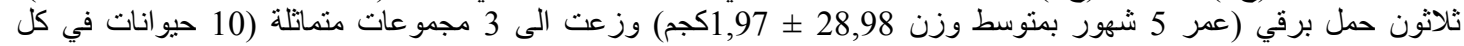

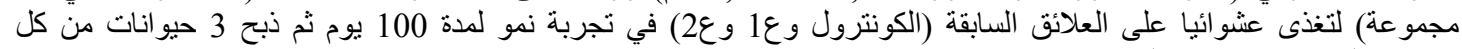

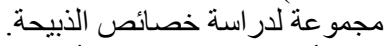

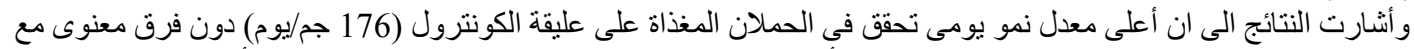

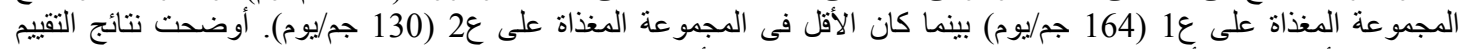

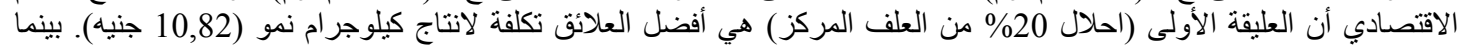

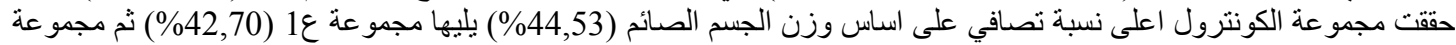

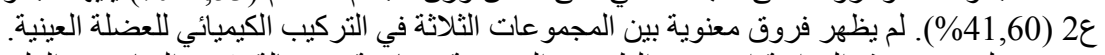

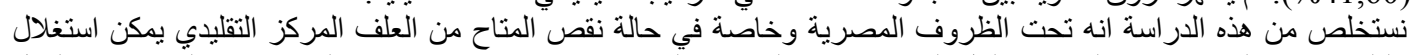

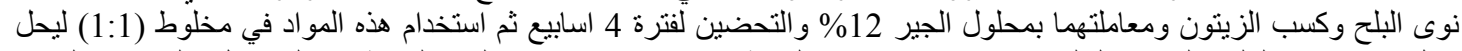

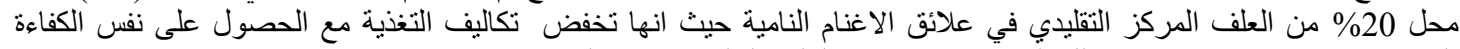
الغذائية ومو اصفات ذبيحة تقارب تلك النّاتجة عن استخدام العلف التقليدي مرتفع الثمن. 